University of Michigan Law School University of Michigan Law School Scholarship Repository

2016

\title{
Social Facts, Legal Fictions, and the Attribution of Slave Status: The Puzzle of Prescription
}

Rebecca J. Scott

University of Michigan Law School, rjscott@umich.edu

Available at: https://repository.law.umich.edu/articles/1835

Follow this and additional works at: https://repository.law.umich.edu/articles

Part of the Constitutional Law Commons, Law and Race Commons, Legal History Commons, and the State and Local Government Law Commons

\section{Recommended Citation}

Scott, Rebecca J. "Social Facts, Legal Fictions, and the Attribution of Slave Status: The Puzzle of Prescription." L. \& Hist. Rev. 35 , no. 1 (2017): 1-22.

This Article is brought to you for free and open access by the Faculty Scholarship at University of Michigan Law School Scholarship Repository. It has been accepted for inclusion in Articles by an authorized administrator of University of Michigan Law School Scholarship Repository. For more information, please contact mlaw.repository@umich.edu. 


\title{
Social Facts, Legal Fictions, and the Attribution of Slave Status: The Puzzle of Prescription
}

\author{
REBECCA J. SCOTT
}

The question of whether one human being is or is not the slave of another might be thought to be rendered altogether moot with the abolition of legal slavery itself. Once the state no longer recognizes the possibility of property in persons, claiming authority under law to exercise the powers attaching to such ownership becomes inadmissible. Even the most egregious

Rebecca J. Scott is Charles Gibson Distinguished University Professor of History and Professor of Law at the University of Michigan <rjscott@umich.edu>. She thanks Leonardo Barbosa, Bethany Berger, Richard Brooks, Kathryn Burns, Ananda Burra, Bridgette Carr, John Cairns, Sidney Chalhoub, Adriana Chira, Brian Costello, Alejandro de la Fuente, Sam Erman, Hussein Fancy, Bruce Frier, Malick Ghachem, Thavolia Glymph, Allison Gorsuch, Ryan Greenwood, Keila Grinberg, Sarah L. H. Gronningsater, Ariela Gross, Gwendolyn Midlo Hall, Hendrik Hartog, Jean Hébrard, Marial Iglesias Utset, Martha S. Jones, Steven Kochevar, Noel Lenski, Beatriz Mamigonian, Olivier Moréteau, Mariana Dias Paes, Agustín Parise, Edgardo Pérez-Morales, Vernon Palmer, Lawrence Powell, Claire Priest, Peter Railton, Dominique Rogers, Michael Ross, JeanFrédéric Schaub, Thomas Scott-Railton, Scott Shapiro, Kimberly Welch, John Witt, and participants in seminars at Stanford University, the Radcliffe Institute, Yale University, and the University of Toronto for suggestions and feedback. She also thanks Juliet Pazera and Sybil Thomas at the New Orleans Notarial Archives Research Center; Irene Wainwright and Greg Osborn at the Louisiana Division of the New Orleans Public Library; Florence Jumonville at the University of New Orleans Library; and the staff of the Office of the Clerk of the Court, Pointe Coupée Parish, Louisiana, for being generous with their time; and Jeanette Diuble, Bryan LaPointe, and Andrew Walker for helping to transcribe case files. Finally, she gives special thanks to the anonymous reviewers of Law and History Review. 
abusers of laborers today would not be so imprudent as to justify their actions by claiming a right of ownership.

With the growth of concern about what is often referred to as modern slavery, however, the question has returned, albeit with a reversal of the valence. If in 1817 a putative master might try to prove that a particular person was his slave, in order to secure control over that person, in 2017 the strategy will be the reverse. A prosecutor will seek to prove that someone has been treated as a slave, in order to bring to bear the criminal and civil penalties that follow from such acts of control. And the exploiter will seek to demonstrate that the laborer was not subjected to conditions analogous to slavery, but was merely a person working in conditions natural to his or her situation: backbreaking field work and rustic lodging for a rural laborer in Brazil, unremunerated domestic service for an adolescent immigrant in Paris, constraints on departure from the workplace for a migrant farm worker transported to an isolated labor camp in North Carolina. ${ }^{1}$

In case after case, prosecutors, judges and juries therefore still struggle to come up with a definition of slavery, looking for some set of criteria or indicia that will enable them to discern whether the phenomenon they are observing constitutes enslavement. In this definitional effort, contemporary jurists may imagine that in the past, surely the question was simpler: someone either was or was not a slave. However, the existence of a set of laws declaring that persons could be owned as property did not, even in the nineteenth century, answer by itself the question of whether a given person was a slave. How was such status to be determined in everyday social life, and how was it determined if disputed in a court of law?

The complexity of the question became explicit in what might otherwise appear to be an arcane detail of the law of slavery: the claim to "freedom by prescription," under which a person who had in good faith "lived as free" could argue that the absence of exercise of ownership for a specified

1. The definition of "conditions analogous to slavery," as enforced in Brazil's domestic labor law and criminal law, is analyzed in Cristiano Paixão and Leonardo Barbosa, "Perspectives on Human Dignity (On Judicial Rulings Regarding Contemporary Slavery in Brazil)," Quaderni Fiorentini per la Storia del Pensiero Giuridico Moderno 44 (2015): 1167-84. The European Court of Human Rights has sought to define forced labor and slavery in a sequence of cases of domestic servitude, beginning with Siliadin v. France (Application no. 73316/01; final judgment issued October 26, 2005), and continuing through C.N. \& V. v. France (Application no. 67724/09; final judgment issued January 11, 2013). Although cases in the United States are often now addressed under the relatively recent Trafficking Victims Protection Act, or under state law, some prosecutions have explicitly drawn on the language of slavery and on federal statutes dating back to the post-Civil War period. See, for example, U.S. v. Tony Booker, 655 F. 2d 562 (4th Cir. 1981), and more generally Bridgette Carr, Anne Milgram, Kathleen Kim, and Stephen Warnath, Human Trafficking Law and Policy (New Providence, NJ: Lexis Nexis, 2014). 
term of years extinguished a prior owner's title to that person as property, and entitled that person to liberty. The present article tracks the concept of freedom by prescription through its intricate relationship with the law of status and the law of property. Although nineteenth century Louisiana provides the examples, the implications extend beyond that unusual mixed civil law/common law jurisdiction.

To anticipate: As courts sought to discern the presence or absence of slave status, they were caught between formal doctrinal arguments that aimed to block claims of freedom by prescription, and competing vernacular understandings of what it meant to "be" free. Moreover, in a set of moves that anticipate modern deliberations about conditions "analogous to slavery," both sides adduced evidence of social relations on the ground and argued about what they implied. Therefore, although status was generally conceptualized as a legal fact that needed simply to be determined, it actually looked much more like a set of practices that needed to be interpreted. ${ }^{2}$

\section{Louisiana}

Jurisdiction depends on sovereignty, and sovereignty shifted with surprising speed in Louisiana. A person born in Pointe Coupée parish in 1789 who never left home would live under Spanish, then (briefly) French, then Territorial, and, finally, Louisiana state law. The resulting layered legal system continued for decades to build upon prior Spanish and French codes and decrees, giving both litigators and judges wide room for maneuver. The drafters of the 1825 Louisiana Civil Code wrote that the various overlapping sources of law available to them in Louisiana had been "so many rich mines from which we can draw treasures of legislation."3

The swapping of legal sources by the state's jurisconsults was matched by evolving vernacular understandings of law, in which popular concepts could persist well beyond changes in codified law, and diverge sharply from formal doctrine. The idea of "freedom by prescription" shows

2. Although color categories are only one component of such disputes over civil status, there is a striking parallel with contemporaneous disputes over racial status. See Ariela Gross, What Blood Won't Tell: A History of Race on Trial in America (Cambridge: Harvard University Press, 2010), especially 56-57, for a discussion of "prescriptive" understandings of race connected to the history of performance or non-performance of various components of civil identity.

3. Quoted in Agustín Parise, "A Constant Give and Take: Tracing Legal Borrowings in the Louisiana Civil Law Experience,” Seton Hall Legislative Journal 35 (2010): 1-35. 
precisely this kind of borrowing, high and low, although its immediate formal origins are clear. The Siete Partidas, compiled for King Alfonso X, el Sabio, in medieval Castille, and widely cited in colonial Spanish America, held that when a slave lived in good faith as a free person for a period of 10 years, in the same land as the master, the person once held as a slave became free, as long as he or she was not a fugitive. ${ }^{4}$

In the section of the Partidas titled "How one gains or loses the ownership of things for time," freedom by prescription appeared among the rules that governed the ways in which ownership of goods could be lost through a lapse of time during which a given piece of property was not claimed. After the specified period of neglect, a former master could not legally reclaim ownership over a person who had without challenge "gone about as free." In parallel with other aspects of property law, freedom by prescription in this form created a defense that a former slave could invoke in the event of an attempt by a former owner to use the law to reimpose control. $^{5}$

4. Las Siete Partidas del Sabio Rey Don Alonso el Nono, glosadas por el Licenciado Gregorio Lopez del Consejo Real de Indias de S. M. Tomo II (Madrid: En la Oficina de Benito Cano, 1789). The first appearance of the rule is in Partida III, Título XXIX, Ley XXIII; the second is in Partida IV, Título XXII, Ley VII. Noel Lenski has pointed out that there is also a precedent in Roman Law. In 300 C.E. or thereabouts, the earlier doctrine of long-term prescriptive acquisition (drawn from property law regarding land, with similar 10 year/ 20 year rules) was cross-applied to the law of persons, allowing for a claim of the acquisition of freedom through long-term possessio libertatis. This made possible an affirmative claim to one's liberty as a person in parallel with the older laws of prescription: "Possession of liberty which began legally and continued for a long time furnishes a full defense. For partiality for freedom and sound reasoning led to the conclusion long ago that those who should remain in possession of liberty for twenty years in good faith and without interruption should be protected against disturbance as to their status by that period of prescription and should become free and be Roman citizens." Diocletian and Maximian, CJ 7.22.2 (300 C. E.), transl. Noel Lenski, in The Codex of Justinian: A New Annotated Translation, with Parallel Latin and Greek Text, ed. Bruce W. Frier, (Cambridge: Cambridge University Press, 2016) 1855; and Noel Lenski, "Constantine and Slavery: Libertas and the Fusion of Roman and Christian Values," Atti dell'Accademia Romanistica Costantiniana 18 (2011): 235-60.

5. Siete Partidas, Partida III, Título XXIX, Ley XXIII. Prescription shares some apparent ancestry with the Anglo-American common law doctrine of adverse possession; however, the provisions of the Siete Partidas do not imply any adverse intent to the possession in question. Indeed, consent by the prior owner can enhance rather than undermine a subsequent claim to freedom by prescription, whereas in common law an owner's previous formal consent to the use of property may defeat a later claim of title by adverse possession. For a careful discussion of intent in modern claims of adverse possession (excluding Louisiana), see Richard H. Helmholz, "Adverse Possession and Subjective Intent," Washington University Law Quarterly 61 (1983): 331-58. 
In the case of slavery, however, the master's failure to exercise ownership during the prescribed number of years did not just cancel the right to later reassert such ownership; it could also liberate the person from the status of "property" altogether. The Siete Partidas introduced this stronger form of the rule in the section titled "On Liberty." This second reference included the affirmative statement that having "gone about on his own" in good faith for the requisite number of years (Andando el sieruo, de alguno por si diez años), believing himself to be free, "he thereby becomes free," or, more literally, "he makes himself thereby free" ( fazese libre porende). This went beyond providing a defense against a possible suit by a former master, and held that the change in status was itself a direct consequence of the passage of time. ${ }^{6}$

Freedom through the passage of time was presumably first introduced in Louisiana as a concept under the period of Spanish colonial rule (roughly 1766-1803); however, it showed remarkable persistence long after the end of Spanish sovereignty, remaining alive despite efforts to extinguish it. Following the incorporation of Louisiana into the United States, the provision was omitted from the 1808 digest of the civil laws in force in Louisiana, twisted into a different meaning in the 1825 Civil Code, and finally attacked in the 1850 s by some of the most adroit lawyers in the state. An argument for "freedom by prescription" nonetheless still functioned as the key element of a successful freedom claim decided by the Louisiana Supreme Court just 5 years before the Civil War initiated the ending of slavery itself.

There is an echo of that persistence in a set of conversations that took place in the 1830 s or 1840 s, approximately 100 miles upriver from New Orleans, in the rural parish of Pointe Coupée. The widow Magdelaine Oliveau Porche, owner of a large plantation situated on the lake called "False River," was talking with her nearest neighbor, a shopkeeper, about the family of a woman named Eulalie Oliveau. Eulalie had once been held as a slave on the Porche plantation, but had been allowed to leave the plantation many years earlier to marry the widow's half-brother, Henri Oliveau, a free man of color. ${ }^{7}$

6. The text from Siete Partidas, Partida IV, Título XXII, Ley VII can be translated as "The servant of someone going about on his own for ten years in good faith, and believing that he was free, in the land in which his master lives, or twenty years in another land, even if his master does not see him, thereby becomes free." "“Andando el sieruo, de alguno por si diez años, auiendo buena fe, e cuydando q[ue] era libre, en aq[ue]lla tierra do morasse su señor, o veynte años en otra tierra, maguer non lo viesse su señor fazese libre porende.").

7. See the testimony of Emmanuel Britto (elsewhere Manuel Brito) in Daniel A. Long v. Lewis E. Smith, Docket No. 8676, First District Court of New Orleans, City Archives, Louisiana Division, New Orleans Public Library (hereafter CA, LD, NOPL). On the 
The widow apparently did not like or trust the kin of her own late husband, and she had no children. Her half-brother Henri Oliveau was her closest family. Moreover, when drawing up her will years later, the widow repeatedly told her lawyer that she wished to free all of her slaves rather than have them pass down as property with her estate. The lawyer, however, flatly refused to file such a request, telling her that a mass grant of freedom of that kind would never be authorized by the local "police jury" (the equivalent of a municipal council). ${ }^{8}$

The shopkeeper Emmanuel Britto, himself a free man of color, asked the widow Porche directly about the status of Eulalie Oliveau, who lacked any written proof of manumission. On this point, the widow apparently assured Britto that having lived as free for so many years with her former owners' consent, Eulalie was legally free "by prescription." The widow also pointed out that since the death of her husband Simon Porche, she had never listed Eulalie as a slave for the purpose of taxation. ${ }^{9}$

When I first came across testimony about these exchanges, I was astonished. First of all, the widow Porche seems to have been a highly eccentric slaveholder, busy struggling with her lawyer to try to get him to help her free every slave on her plantation. Moreover, in chatting with her shopkeeper neighbor she invoked a somewhat arcane (and formally extinct) civil law doctrine concerning freedom by prescription. "Prescription" in this sense was presumably not a household word, and these were two residents of rural Louisiana, one of whom had perhaps migrated from the Caribbean, but the other of whom seems never to have gone farther from False River than an occasional trip to New Orleans. ${ }^{10}$

Did neighbors, ordinary jurors, and perhaps even trial judges in antebellum Louisiana actually take 10 years lived as free to be a pathway to legal freedom and, therefore, a change of civil status? New Orleans held the largest slave market in the United States, and the use of enslaved labor on

microfilm copy available at the NOPL, the testimony in the case is interleaved with the closely related case titled Eulalie and her descendants v. Long \& Mabry, Docket No. 8668.

8. See the testimony of the widow's personal lawyer, Alphonse Robin, as transcribed in the manuscript record of Eulalie, f.w.c., et al v. Long et al, Docket No. 3979, New Orleans, June 1856, Louisiana Supreme Court, in Historical Archives of the Supreme Court of Louisiana, Special Collections, Earl K. Long Library, University of New Orleans (hereafter LSC, HASCL), 15-18.

9. See the testimony of Emmanuel Britto, in Daniel A. Long v. Lewis E. Smith, Docket No. 8676, CA, LD, NOPL.

10. Manuel Britto was listed in the 1870 census as a "mulatto," born in approximately 1806 in Spain, which may well mean Spanish Cuba. See Family 223, Ward 9, Pointe Coupée Parish, Louisiana, on the manuscript schedules of the Ninth Census of the United States, United States National Archives (hereafter USNA), reproduced on USNA microfilm publication M593, accessed through ancestry.com. 
Louisiana's sugar and cotton plantations had permitted the amassing of great fortunes. A rule that enabled some men and women to make their way out of bondage was hardly likely to win favor with slaveholders and lawmakers.

The path of the concept from medieval Spain to antebellum Pointe Coupée turns out to have been a winding one. In the portion of the 1803 Louisiana Purchase that became the United States Territory of Orleans, and later the state of Louisiana, much of Spanish law (along with French law) was initially held to continue to apply in the civil sphere, in order to avoid disruption of social and property relations. Within a few years, however, the territorial legislature charged the Saint-Domingue émigré slaveholder Louis Moreau Lislet with the task of drafting, along with James Brown, what they anticipated would be a full civil code for the new Territory of Orleans. ${ }^{11}$

Moreau Lislet, who had been a jurist in Saint-Domingue during the Haitian Revolution, certainly knew the ins and outs of laws governing slavery. He had also spent time as a refugee in Spanish Cuba, and he would later collaborate on a translation into English of the Siete Partidas. The text that he and Brown prepared for the legislature did discuss prescription with reference to slaves, but only insofar as it concerned competing claims as between putative owners, on parallel with other forms of property, not as an avenue to freedom for the person claimed. In the draft that they prepared, the awkward doctrine of freedom by prescription did not appear. ${ }^{12}$

11. See Vernon Palmer, "The Quest to Implant the Civilian Method in Louisiana: Tracing the Origins of Judicial Methodology," Louisiana Law Review 73(2013): 793-819; and John Cairns, "Blackstone in the Bayous: Inscribing Slavery in the Louisiana Digest of 1808," in Re-Interpreting Blackstone's Commentaries: A Seminal Text in National and International Contexts, ed. Wilf Prest (Oxford: Hart Publishing, 2014), 73-94.

12. See Book III, Title XX, Chapter III, Section III, Article 74, A Digest of the Civil Laws Now in Force in the Territory of Orleans (1808, reprint ed. Baton Rouge: Claitors's Publishing Division, 2007): "Slaves may be prescribed for in half the time required for the prescription of immoveable estate and in the same manner and subject to the same exceptions;" and Vernon Valentine Palmer, Through the Codes Darkly: Slave Law and Civil Law in Louisiana (Clark, NJ: The Lawbook Exchange, Ltd., 2012), 147-49. Law in the French colonies did not include the formal doctrine of freedom by prescription, generally describing apparent slaves without masters as épaves, the equivalent of flotsam, jetsam, or a shipwrecked boat, available for claiming. Even when this rule changed in the French colonies under the Restoration, the concession to freedom was grudging. Those perceived as slaves who were found not to have been properly inscribed in the census, or otherwise without a documented owner, were no longer épaves, but they were required to serve the state for another 7 years. See Section 7, Article 2, of the Ordonnance du Roi sur les recensements dans les colonies, 11 June 1839, listed as No. 91 in Annales Maritimes et Coloniales. Partie Officielle. 1839. (Paris: L'Imprimerie Royale, 1839) 552-57. 
When the draft was passed into law by the legislature, Brown and Moreau Lislet's text was designated a "digest," not a fully controlling civil code. In the years that followed, the members of the Louisiana Supreme Court jealously guarded their right to pick and choose from the voluminous body of prior Spanish and French law as well as the Digest itself. As Vernon Palmer has demonstrated, this allowed the court to have a high degree of flexibility and discretion, rather than be restricted to finding answers in the fixed rules of a code. ${ }^{13}$

Although the doctrine of freedom by prescription was missing from the 1808 Digest, it remained present in recent legal memory, along with its parent text, the Castilian Siete Partidas. In 1818-19 the Louisiana Supreme Court confronted the issue when a refugee from Saint-Domingue named Adélaïde Métayer, who had lived as free for many years, sought to defend herself against an attempted re-enslavement. ${ }^{14}$ After a tangled set of trials and appeals, the state Supreme Court declared Adélaïde Métayer to be free "by prescription."15

The decision went into the official record, and was reflected in compilations of key Louisiana Supreme Court cases regarding manumission and emancipation. Soon any lawyer or magistrate could easily locate a reference to the "time necessary for prescription" of a slave who claimed to have enjoyed liberty. The medieval Spanish rule appeared to have returned in force. ${ }^{16}$

I will pause here to address a potential question: why would any slaveholding jurisdiction allow freedom by prescription? A master's ability to manumit slaves was often legally constrained by state-mandated requirements on age and conduct, and might require formal approval or fees.

13. Palmer, Through the Codes; and "The Quest to Implant the Civilian Method in Louisiana."

14. Many migrants from Saint-Domingue could in principle claim to have lived as free in good faith as a consequence of the emancipation ratified by the French National Convention in 1794. For an overview of reported suits, see Sue Peabody, "Free upon higher ground': Saint-Domingue Slaves' Suits for Freedom in U.S. Courts, 1792-1830," in The World of the Haitian Revolution, ed. David Patrick Geggus and Norman Fiering (Bloomington: Indiana University Press, 2009), 261-83.

15. Metayer v. Metayer, 6 Mart. (o.s.) 16 (La. 1819). For detailed discussions of the case, see Rebecca J. Scott, “'She Refuses to Deliver Up Herself as the Slave of Your Petitioner': Émigrés, Enslavement, and the 1808 Louisiana Digest of the Civil Laws," Tulane European \& Civil Law Forum 24 (2009): 115-36; and "Paper Thin: Freedom and Re-enslavement in the Diaspora of the Haitian Revolution," Law and History Review 29 (2011): 915-24.

16. See, for example, Judah Philip Benjamin and Thomas Slidell, Digest of the Reported Decisions of the Superior Court of the Late Territory of Orleans, and of the Supreme Court of the State of Louisiana (New Orleans: J. F. Carter, 1834), 124, in the section titled "emancipation." 
Why should the master's neglect be able to do what the master's intent could not, freeing a slave simply through the passage of time spent out of the possession of the master? ${ }^{17}$

Perhaps one answer, oddly, lies in the importance of resolving the obverse of that same principle. Did years held as a slave make one a slave? In their original form, the Siete Partidas explicitly held that a free person could not be transformed into a slave by the mere passage of time held as if a slave. In practice, however, nineteenth century slaveholding societies made it relatively easy to assert ownership over persons, without any particular proof of legitimate acquisition. An implicit rule making legal status congruent with apparent social position could thus operate in the general interest of putative owners. Slave status, in effect, could be based on something that looked rather like simple present possession, deflecting inconvenient inquiry into the (perhaps altogether absent) root of the alleged title. ${ }^{18}$

The consequences were dramatic. In Louisiana, at least 3000 of the refugees originally from French colonial Saint-Domingue who entered New Orleans in 1809 were claimed by others as slaves more than a year after the Congressional ban on bringing persons into the United States for use or sale as slaves, and despite the fact that these persons had nearly all been free under French law at the time of their initial departure from the colony in 1803. (Most had been in Cuba in the meanwhile.) Although putative owners were initially required to post bond, pending a decision on the applicability of the federal statute, they did not have to show title. The

17. Lawyers arguing against specific claims of freedom by prescription were quick to point out this apparent inconsistency. See the discussion of cases in Andrew T. Fede, Roadblocks to Freedom: Slavery and Manumission in the United States South (New Orleans: Quid Pro Books, 2011). Steven Kochevar argues that in Anglo-American property law "Adverse possession shifts title when community members perceive the adverse possessor, instead of the original titleholder, as the owner of property," and thus functions in the long run to maximize the legitimacy of legal title itself. See Kochevar, "Adverse Possession as Localism," Working Paper, 2015. In civil law jurisdictions, freedom by prescription functioned somewhat differently, but shared the element of community recognition. The question, however, was: Which community? That of slave traders and their clients, or that of neighbors sympathetic to a specific family's claim to freedom?

18. Partida III, Título XXIX, Ley XXIV of the Siete Partidas. Although the implicit rule in Louisiana was that those held as slaves were presumed to be slaves, a putative owner could face difficulties if he or she sought to use the law to gain actual possession of a person who claimed to be a free person. In one such suit in 1824, the Louisiana Supreme Court did confirm that slave status could not be created simply by holding a free person as a slave. See Delphine v. Deveze, Docket No. 996, Eastern District, LSC, HASCL; decision 2 Mart. (n.s.) 650 (1824). Again, there is Roman precedent: the Codex of Justinian titles a relevant section "Long Time Prescription, which may be used in favor of but not opposed to liberty." CJ 7.22. 
appearance of control over a person deemed to be of African descent would generally do the trick. Within a matter of months the bonds had all been released, and the government authorized the alleged "owners" to exercise full property rights over their "slaves." One can see a possible reason for Louisiana Supreme Court Justice Derbigny's later comment that the refugee Adélaïde Métayer's refusal to acknowledge slave status raised a "very delicate subject." 19

Within these background conventions, it was not mere color that performed the alchemy of creating status out of circumstances. Another 3000 among the arriving Saint-Domingue refugees convincingly occupied a social position as free people deemed to be either Black or "of color," and were categorized as such upon arrival in New Orleans. A few of them registered manumission papers or copies of their baptismal records at the mayor's office or with a notary; most did not. They appeared to be masters and mistresses of themselves, and their apparent possession of the status of free person was implicitly taken to be evidence that they had a legal right to that status. $^{20}$ (Indeed, some were exercising control over other persons whom they claimed as their slaves.) They benefitted in practice from what French civil law doctrine had called possession d'état, legal recognition of a status confirmed by living publicly in accord with its attributes. ${ }^{21}$

19. Metayer v. Metayer 6 Mart. (o.s.) 16 (La. 1819), 18. On the large scale re-enslavement of Saint-Domingue refugees in Louisiana, see Rebecca J. Scott and Jean M. Hébrard, Freedom Papers: An Atlantic Odyssey in the Age of Emancipation (Cambridge: Harvard University Press, 2012), 65-70. Many thousands of Africans brought to Brazil in violation of both international and domestic law were similarly "owned" as property in the nineteenth century, making any inquiry into status potentially delicate. See Beatriz Mamigonian, "O Estado Nacional e a Instabilidade da Propriedade Escrava: A Lei de 1831 e a matrícula dos escravos de 1872," Almanack 2 (2011): 20-37; and Sidney Chalhoub, A força da escravidão: Ilegalidade e costume no Brasil oitocentista (São Paulo: Companhia das Letras, 2012).

20. Despite occasional declarations that free people of color should provide written or oral proof of status, the government of the Territory of Orleans does not seem to have to have taken steps to inquire systematically into the status of individual refugees. On the categorization of arriving refugees, see Scott and Hébrard, Freedom Papers, 67-68, 210 n6.

21. On possession d'état de libre, see Dominique Rogers, "On the Road to Citizenship: The Complex Route to Integration of the Free People of Color in the Two Capitals of Saint Domingue," in Geggus and Fiering, World of the Haitian Revolution, 65-78. This doctrine may have been in some tension with the rule that an unowned "slave" was simply property that was now épave, like a wrecked ship available for salvage. Individual judgments presumably turned on showing evidence of social standing as free. See also Adriana Chira's discussion of "tener por libre" (to take as free) in "Uneasy Intimacies: Race, Family, and Property in Santiago de Cuba, 1803-1868," PhD diss., University of Michigan Program in Anthropology and History, 2016. 
Up to a point, then, freedom could be maintained by the performance of freedom. In that sense, the doctrine of "freedom by prescription" simply served to formalize the length of time during which such publicly recognized behavior had to be sustained in order to be legally acknowledged. ${ }^{22}$

Cases such as that of the Saint-Domingue refugee Adélaïde Métayer highlighted the complexity of the legal question. She had lived as a free woman for many years when in 1810 a neighbor with whom she had apparently once cohabited came forward in New Orleans, claimed that he was owed a debt by her former owner, and seized her and her children as "property" to cover that debt. By order of the court, one of Adélaïde's children was sold at auction; the rest of the family was released when the amount of the debt had been covered by the proceeds of that auction. ${ }^{23}$

A few years later, the same neighbor, Louis Noret, acquired a power of attorney from the heir of Adélaïde's former owner, Pierre Métayer, now a merchant living in New York, and seized her again, this time on Pierre Métayer's behalf. Adélaïde found a lawyer to take the case to court. She produced witnesses who supported her claim to have long "enjoyed her freedom," providing a detailed narrative of her time in revolutionary Saint-Domingue, in New York, and in Baracoa, Cuba. By consent of the parties, the case went before a jury. They promptly found in Adélaïde Métayer's favor. ${ }^{24}$

22. Kenneth Aslakson, in a recent work, argues that distinctions construed as differences in "color" could be crucial in affecting presumptions of status. He concludes that after the 1811 Louisiana Superior Court ruling in Adele v. Beauregard, a "Negro" faced the burden of proof in a freedom suit, whereas an individual deemed "of color" could invoke a presumption of free status and shift the burden of proof to the person holding him or her as a slave. See Kenneth R. Aslakson, Making Race in the Courtroom: The Legal Construction of Three Races in Early New Orleans (New York: New York University Press, 2014). Aslakson argues that this decision helped "to create a particular racial identity," that of a "person of color," as distinct from a "Negro." He notes that the case was cited in six subsequent Louisiana Supreme Court decisions. However, it remains to be seen whether the reasoning in Adele v. Beauregard (which the court enunciated in part as a hypothetical) actually controlled legal presumptions and practice in a state that saw a mountain of litigation concerning slavery over the next 50 years (Aslakson, Making Race, 181). Debate is likely to continue, moreover, on whether the complex and evolving social categories of New Orleans are best captured by the idea of "three races."

23. The 1810 events occasioned two cases in the City Court: L. Noret v. L. Meteyer, Docket No. 2093, for the recognition of the debt; and A. Metayer v. B. Cenas, Docket No. 2241, challenging the seizure by the sheriff and Noret. Both are in CA, LD, NOPL.

24. Métayé v. Noret, Parish Court, Docket No. 1035, CA, LD, NOPL. Correspondence introduced in this case suggests that at some point in her journeys, Adélaïde began to use the surname Durand. The court, however, continued to treat her as Adélaïde Métayer. For most purposes, I retain Métayer here because of its use in the testimony and on the court docket. 
When these eleven white residents of New Orleans heard testimony on Adélaïde Métayer's history and her comportment over the previous decades, they apparently came to believe that they were "seeing" a femme de couleur libre, a free woman of color, not a slave. In other words, a rough-and-ready popular understanding of the principle underlying prescription brought her legal status into line with a social position gained through long years in which, to use the words of the original provision in the Siete Partidas, she had been "going about on her own." 25

Louis Noret appealed the trial court's decision to the Louisiana Supreme Court. Although accepting the possibility of freedom by prescription, the Supreme Court held that the 20 year version of the rule from the Siete Partidas - in which the claimant had lived in a land different from that of the master - applied in this case. If one counted from the date of an informal agreement that Adélaïde had negotiated with her former master back in Saint-Domingue in 1801, she had lived as free for too short a period to establish legal freedom. On April 13, 1818, the Louisiana Supreme Court declared her to be the slave of Pierre Métayer. ${ }^{26}$

Armed with this ruling, Pierre Métayer tried to take possession of Adélaïde Métayer. She nonetheless eluded his grasp. After some weeks, he petitioned the parish court to try to gain assistance in forcing Adélaïde to "give up herself" to him as his slave. She again fought the effort in court, reiterating the story of her years lived as free, and bringing in witnesses who testified that a decade earlier Pierre Métayer had been in Cuba and had known that she was living as a free woman there, but had taken no steps to assert ownership over her. ${ }^{27}$

Judge James Pitot of the local court seems to have found the behavior of Louis Noret and Pierre Métayer somewhat distasteful, and he implied that it was perhaps connected to the grievances of a "bastard sister" of Pierre Métayer who was living with Louis Noret as his "housekeeper." The judge declared himself persuaded that Adélaïde Métayer had "never behaved in a suspicious blamable manner in order to conceal her person

25. Métayé v. Noret, Parish Court, Docket No. 1035, CA, LD, NOPL. The jury foreman, René Delarue, seems to have been a French-born man much engaged in the buying and selling of slaves. (See multiple entries in Gwendolyn Midlo Hall, comp., "Afro-Louisiana History and Genealogy, 1719-1820," now accessible through ancestry.com.) One of the members of the jury may have been Jean Boulard, who in his will declared that he was the father of a "natural child" of color, born of a free woman of color. (The 1817 will of Jean Boulard is in Will Book, Vol. 3, Civil District Court, Orleans Parish, CA, LD, NOPL; digital scan accessible through ancestry.com.)

26. The Supreme Court case is Docket No. 288, Noret v. Métayer, in HASCL, UNO. The decision is 5 Mart. (o.s.) 566 (La. 1819).

27. Metayer v. Metayer, Docket No. 1589, Parish Court, CA, LD, NOPL. 
for the enjoyment of a doubtful liberty." She had by contrast "been made free by the French Commissaries toward 1794 and never tried to take advantage of it." Taking into account her lawyer's explicit appeal to prescription, Judge Pitot ruled that Adélaïde Métayer and her daughters "must be protected by our Law in the enjoyment of their freedom." 28

Pierre Métayer immediately appealed Judge Pitot's decision back up to the Louisiana Supreme Court, obliging the justices to reconsider the question of Adélaïde Métayer's status. Pierre Métayer was represented by the distinguished lawyer Henry Carleton, but the terrain had changed. The trial court had now raised the delicate question of the 1793 decrees of abolition issued by the Civil Commissioners in Saint-Domingue, and by implication the 1794 law of abolition passed by the French National Convention. The Supreme Court was unlikely to conclude that actions so closely linked to the French and Haitian Revolutions had direct effect under Louisiana law, but Justice Derbigny was nonetheless persuaded that they had conferred freedom "in fact" on Adélaïde Métayer during the time that she had remained in Saint-Domingue. She was thus not a fugitive. And if one started the clock in 1793/94 instead of 1801, she had indeed lived 23 years as free, and believing herself to be free, by the time Pierre Métayer first tried to claim her in 1816. Therefore, free she was, under the logic of the Siete Partidas. ${ }^{29}$

In effect, the court had vindicated both the liberty and the property variants of the principle of prescription from the Siete Partidas, allowing Adélaïde to sue Louis Noret (albeit unsuccessfully), and blocking Pierre Métayer from using law to claim her as property. On this interpretation, the legacy of the Partidas could create an affirmative right to freedom through the passage of time, and with it, standing and cause of action sufficient to bring a suit to establish free status, as well as a defense if a putative owner sued to seek possession. The court had judged the underlying Spanish law to be still available as a pleading in this domain, because subsequent Louisiana law had not explicitly repealed or contradicted it.

28. Judge Pitot's final decision appears in the re-transcription of these proceedings in the subsequent appeal to the Louisiana Supreme Court (see note 29 below). The half-sister of Pierre Métayer was a woman of color named Daine, "natural child" of Charles Métayer. Daine had once been a slave in the Métayer household and was said to have later been the ménagère of Louis Noret, a term meaning "housekeeper," which in this context suggested sexual intimacy. There was no direct testimony suggesting rivalry between Daine and Adélaïde, and the implied hypothesis of the ménagère's jealousy seems a less likely explanation of Louis Noret and Pierre Métayer's multi-year campaign of enslavement than bitterness about events in Saint-Domingue and sheer greed at the prospect of converting a woman and her several children into salable property.

29. The second appeal is Peter Métayer v. Adelaide f.w.c., Docket No. 318, in HASCL. The decision is Métayer v. Métayer, 6 Mart. (o.s.) 16 (La. 1819). 
Evidently, the omission of the doctrine of "freedom by prescription" from the 1808 Digest of the Civil Laws had not in practice extinguished it.

The next year, the jurists Louis Moreau Lislet and Henry Carleton (who had represented Louis Noret and Pierre Métayer respectively in the efforts to enslave Adélaïde Métayer) published a volume titled The Laws of the Siete Partidas Which are Still in Force in the State of Louisiana, Translated from the Spanish. Presumably following the lead of the decision in Métayer v. Métayer, and in contrast to the omission of freedom by prescription in the 1808 Louisiana Digest, they-one imagines grudgingly-included freedom through the passage of time in the section of the Partidas titled "On Liberty." The translators labeled the provision "In what manner a slave may acquire his freedom by prescription," although the word "prescription" had not appeared in the Spanish original. Their (loose) translation continued "If a slave enjoy his freedom, during ten years, in good faith, believing he was free, in the country where his master lives; or during twenty years, in any other country, although his master should not see him, he becomes thereby free." 30

Although the Moreau Lislet/Carleton translation was not precisely an official legal document, its production had been commissioned by the legislature. Combined with the decision in Métayer v. Métayer, it could fix in the minds of those studying or practicing law in Louisiana the conviction that freedom by prescription was a live doctrine in the jurisdiction. This doctrine was nonetheless in some tension with other decisions on slavery, including an 1817 judgment that a slave had no right to challenge at law the validity of the title by which he or she was held as a slave. The person held or claimed as a slave could seek only a judgment of liber vel non, free or not. Any inquiry into the specific title was out of order, and a putative owner could not be obliged to show the title. ${ }^{31}$

30. Moreau Lislet was the judge in the City Court who first authorized Louis Noret to seize "property" belonging to the late Charles Métayer in order to satisfy the alleged debt. He later represented Noret in the Orleans Parish District Court. Henry Carleton co-signed Noret's appeal bond, and represented him before the Louisiana Supreme Court. The Moreau Lislet/Carleton translation was published in New Orleans by James M'Karaher in 1820; the cited text is on page 591. The less categorical version of the prescription principle from Partida III is on pp. 386-87. See also Agustín Parise, "Introductory Essay on the Translators' Preface to Las Siete Partidas," Journal of Civil Law Studies 7 (2014): 311-35.

31. "Owners ought not to be subjected to support or exhibit their titles, contradictorily with their slaves." Trudeau's Executor v. Robinette 4 Mart. (o.s.) 577 (1817) at 581. See also Judith Kelleher Schafer, Slavery, the Civil Law, and the Supreme Court of Louisiana (Baton Rouge: Louisiana State University Press, 1994) 224. The decision in Trudeau's Executor v. Robinette presumed a prior finding of slave status, resting on acts of sale and the absence of a demonstrated manumission. 
As plantation society in Louisiana hardened, and both the sugar industry and the slave market expanded, the doctrine of freedom by prescription was increasingly at odds with masters' search for unquestioned power over those they claimed as slaves. When in 1822 the Louisiana Legislature commissioned a full Civil Code, the drafters took a new tack, seeking to eliminate direct appeal to any underlying Spanish law by redefining the provision in such a way as to supersede the Siete Partidas on this point. ${ }^{32}$

This time, Louis Moreau Lislet and his new coauthors inserted an explicit provision on prescription as related to slavery: the eventual Article 3510 of what would become the 1825 Civil Code. In the process, they did two things to narrow the doctrine: they kept the provision on prescription away from any discussion of liberty and emancipation, inserting it only in a section on property, labeled "Of Occupancy, Possession, and Prescription," and although their draft cited the Siete Partidas as its source, they crucially altered the wording: "If a master suffer a slave to enjoy his liberty for ten years, during his residence in the State, or for twenty years while out of it, he shall lose all right of action to recover possession of the slave, unless the slave be a runaway or a fugitive." The language looked superficially similar; however, the subject of the article was now the putative master rather than the person claimed as a slave. The reference to the former slave's change of status - "he becomes thereby free"-had been removed. ${ }^{33}$

The drafters thus effectively shifted prescription with regard to slaves away from the zone where it might create a cause of action through which the person held as a slave could initiate a legal claim to freedom by prescription, and into a zone where it simply imposed a time limitation on a suit by a putative owner seeking to use the law to regain possession. The new Article 3510 also did not repeat the language in the translation of the Siete Partidas that held that if taken to court the person claimed as a slave "may avail himself of this prescription and obtain his freedom." 34

By explicitly addressing the question of prescription, the drafters had blocked plaintiffs from pleading Spanish law on the grounds that the question had not been addressed in subsequent Louisiana law. To complete the

32. On the drafters, see C. Russell Reynolds, "Alfonso el Sabio's Laws Survive in the Civil Code of Louisiana," Louisiana History 12 (1971): 137-47; and Rodolfo Batiza, "The Actual Sources of the Louisiana Projet of 1823: A General Analytical Survey," Tulane Law Review 47 (1972) 1-115.

33. See Louisiana Legal Archives, Vol. 1. A Republication of the Projet of the Civil Code of Louisiana of 1825 (New Orleans: T. J. Moran's Sons, 1937), 414, in the section "Of the prescription of ten years." Unsurprisingly, the source citation to the Siete Partidas is to the property version in Partida III, not the liberty version in Partida IV.

34. The quoted phrase is from the 1820 Moreau Lislet and Carleton translation of the Siete Partidas, Vol. 1, 387. 
burial, Article 3521 of the new Code explicitly held that the Spanish, Roman, and French laws of colonial Louisiana could no longer be invoked "even under the pretence that their provisions are not contrary or repugnant to those of this Code." 35

While a person living as free might still try to plead the defense of prescription to counter a legal attempt at enslavement by the former master, the reformulated language of Article 3510 seemed not to allow an affirmative claim to self-ownership as against the world or as against the state. What recourse was available, then, if a person who had long lived as free was simply to be seized and offered for sale as a slave? $?^{36}$

\section{Eulalie Oliveau and her Children}

Despite the best efforts of the drafters of the 1825 Civil Code, the concept of freedom gained through years lived in good faith as free continued to linger in popular legal consciousness. It was apparently alive and well in Pointe Coupée Parish in the 1830s or 1840s when the widow Magdelaine Oliveau Porche so confidently assured her neighbor Emmanuel Britto that the family of Eulalie Oliveau was securely free "by prescription." Eulalie had decades earlier been listed as a young enslaved domestique on the estate inherited by Magdelaine Oliveau Porche. As was often the case in Pointe Coupée, Magdelaine herself had kin who were part of her white family - those who were, like her, born to her father and his legal wife - and others who were part of a family of color - those born to her father and an enslaved women, and later manumitted. Magdelaine's "natural brother" Henri Oliveau was in the latter category. It was probably around 1808 that Henri sought permission from his half-sister and her husband to marry Eulalie, allowing the young woman to depart the plantation and, by implication, exit from slavery. Permission was granted. Over the next years, Henri and Eulalie Oliveau lived on a farm across False River from the Porche plantation, and raised a family of

35. See General Assembly, Civil Code of the State of Louisiana ([New Orleans?]: Published by a Citizen of Louisiana, 1825).

36. One Louisiana lawyer argued in 1857 that any freedom gained through prescription was "inchoate;" un-perfected unless there had been judicial process. Hence despite the passage of the requisite number of years, the claimant could be denied access to the status of a free person. See "Police Matters," Daily Picayune, July 9, 1857, 1; also cited by Judith Kelleher Shafer, Becoming Free, Remaining Free: Manumission and Enslavement in New Orleans, 1846-1862 (Baton Rouge: Louisiana State University Press, 2003), 67, who identifies the argument with attorney Alexander P. Field. 
children and grandchildren. Eulalie crossed the lake on occasion to attend as a midwife to women on the plantation, and was paid for her services. ${ }^{37}$

In 1850, the widow Porche died at the age of 85, and her estate went to her grand-niece, Virginie Esneault. The year before the widow's death, however, an alleged "sale" document had been quietly drawn up in the parish. In it, Eulalie and her children were ostensibly "sold" by the widow to Louis Esneault, Virginie's brother, with a clause committing Louis to formally free the family as soon as possible. If it was more than a pure forgery, the "sale" is likely to have been effected by manipulating the elderly widow's fear for Eulalie and Henri Oliveau's future, and promising to secure proper freedom papers for their family. In any event, very few people seem to have known about this apparent transaction. ${ }^{38}$

Perhaps frustrated that the estate that his sister had just inherited turned out to have been heavily mortgaged, Louis Esneault soon put into action a plan to try to transmute Eulalie Oliveau and her family into cash. In early February 1853, he arranged for a gang led by an overseer from a neighboring plantation to seize Eulalie along with six of her children and eleven of her grandchildren. They were sent on a steamer down river to New Orleans, having been "sold" on paper to two slave traders, Daniel Long and Zachariah Mabry. (The proceeds of a subsequent sale of six of the children and grandchildren to another trader, however, would actually be cashed at a bank in New Orleans by Louis Esneault.) ${ }^{39}$

Back in False River, Eulalie's husband Henri, whom the kidnappers had beaten but not taken, arranged for a local lawyer, William Beatty, to try to retrieve the family. After tracking the slave traders, and negotiating with their attorneys, Beatty tried to bring suit for the freedom of the family in the First District Court of New Orleans. The judge dismissed the suit on "an exception of no cause of action," but Beatty and a second attorney appealed, and won a ruling from the Louisiana Supreme Court remanding the case for trial. ${ }^{40}$

37. Eulalie Oliveau's family history is documented in judicial, property, and inheritance records now held in the Office of the Clerk of the Court, Pointe Coupée Parish, New Roads, Louisiana; in sacramental records in the archives of the Diocese of Baton Rouge; and in the notarial records of New Orleans, as well as in the case files cited in notes 39, 40 and 41 below. Her experience is analyzed in detail in Rebecca J. Scott, "Unlawful Powers: The Making and Breaking of Property in Persons," manuscript in preparation.

38. Esneault did not try to offer this document as proof of ownership, and most of his neighbors apparently had no knowledge of it. See Vente d'esclaves Par Ve Simon Porche à Louis Esneault, March 31, 1849, Filed for record, April 23, 1849, Act 998, Property Records, 1849, Office of the Clerk of the Court, Pointe Coupée Parish.

39. See the testimony of David M. Matthews about "Mr. Heno" in Eulalie, f.w.c., et al v. Long et al, Docket No. 3979, LSC, HASCL.

40. Eulalie and her children v. Long \& Mabry, 9 La. Ann 9 (1854). By the time the case reached the First District Court on remand, a different trial judge had been seated. 
At trial, Eulalie Oliveau's lawyers introduced multiple depositions confirming that she had lived for more than 40 years with her husband Henri Oliveau on their own farm, and that when she did work on the widow Porche's plantation, it was as a paid midwife. Even the widow's exasperated former lawyer confirmed that he had long believed Eulalie and Henri Oliveau's family to be free by prescription. The slave traders tried to argue that one of Eulalie's daughters had once been whipped by an overseer, and that this was a sign of slave status, but on the whole they had little in the way of fact on their side. Therefore, their attorney instead argued the law, asserting that the case should be dismissed because Article 3510 of the Louisiana Civil Code did not provide a legal cause of action on which to base a suit of the kind Eulalie Oliveau had initiated, and because his clients were innocent of any act of violence. ${ }^{41}$

As in the cases involving Adélaïde Métayer decades earlier, when faced with abundant evidence of life as a free woman, the trial court ruled in favor of the freedom of Eulalie Oliveau and her descendants. The judge delivered himself of a self-congratulatory disquisition in which he cited the Siete Partidas as the source of the relevant article of the 1825 Civil Code, and described Louisiana slave law as exceptionally humane. (This at a time when a Louisiana statute made it a capital crime to stimulate discontent among slaves or free people of color.) $)^{42}$

The slave traders who had participated in the kidnapping plot, Long and Mabry, appealed the decision to the Louisiana Supreme Court. Their lawyer once again argued strenuously that Eulalie Oliveau's claims should be dismissed on the grounds that she had no cause of action, because the mere rule about prescription found in Article 3510 of the Civil Code did not confer on a person held as a slave the right to bring suit. ${ }^{43}$

Half a century after Louisiana had become part of the United States, there seemed still to be a tension between formal jurisprudence, which was being continually adjusted to tighten up the slave system against exit and challenge, and informal legal understandings of the kind shared

41. Most of the original testimony in Eulalie \& her descendants vs. Long \& Mabry, Docket No. 8668, First District Court, CA, LD, NOPL, is re-transcribed in Eulalie, f.w.c. et al v. Long et al., Docket No. 3979, in LSC, HASCL.

42. See the report of the trial judge's statements in "Local Intelligence," The Daily True Delta (New Orleans), December 16, 1854. On the punishment for inciting discontent, see "An Act to punish the crimes therein mentioned, and for other purposes," Approved March 16, 1830, in Louisiana, Acts at the Second Session of the Ninth Legislature, 96-97.

43. For a careful exploration of this alleged bar to the suit, see Ananda Burra, "The Exception of 'No Cause of Action': Procedural Barriers to a Prescriptive Claim of Freedom From Slavery," research paper prepared for the seminar "The Law in Slavery and Freedom," University of Michigan Law School, AY2013/ 2014, revised version February 2, 2014. 
by Magdelaine Oliveau Porche, who had released Eulalie Oliveau around 1808; by the shopkeeper Emmanuel Britto, who was prepared to testify that Eulalie's children and grandchildren had always lived as free persons; and even by the trial court judge, who fondly quoted the Siete Partidas.

What, then, was the Louisiana Supreme Court to do in the face of this final appeal by the slave traders, who were ably represented by the New Orleans attorney Robert Hardin Marr? It was now 1856. Dred Scott v. Sandford was making its way through the courts, and the Louisiana legislature was on the verge of prohibiting all future manumissions of slaves in the state. To the extent that the defense of slavery was a defense of property rights, however, surely slave property, like all other property, was subject to some form of prescription, some rule that might situate a new title in a long-uncontested possessor. Eulalie Oliveau had in effect possessed her own self in good faith for 45 years. Was she not, then, mistress of her own person? On behalf of the slave traders Daniel Long and Zachariah Mabry, R. H. Marr insisted that she was not. ${ }^{44}$

The solution that the court found was peculiar, but perhaps not surprising. The judges split three to two. The majority ruled that Article 3510 did allow for a slave to acquire freedom by prescription, and that Eulalie Oliveau and her family were to be set at liberty. Long and Mabry, who had already sold six of the children and grandchildren whom they had seized, and had been trying to sell Eulalie and her other children, were not to trouble her further. The two remaining justices, however, insisted in a separate concurrence that although Eulalie Oliveau should be set at liberty, her status should not be viewed as having changed. She was to be freed from her captors, but she was not to be declared at law to be a free woman. ${ }^{45}$

Although the three-judge majority clearly endorsed legal freedom for Eulalie, somehow the two concurring judges got the ear of the clerk recording the decision, William M. Randolph. The official headnote thus accorded one line to the majority opinion ("Under Article 3510 of the Code a slave may acquire freedom by prescription"), and eight lines to the concurrence that narrowed its scope: "Article 3510 of the Code was not intended to introduce a mode of emancipating slaves, or of changing their status. It treats of the slave as being still a slave after the ten years enjoyment of his freedom..." A reader of the headnote might well infer that prescription could indeed require freeing a slave from the putative owner's possession, but that it did not thereby alter the civil status of the

44. Eulalie, f.w.c., et al v. Long et al, Docket No. 3979, LSC, HASCL.

45. Eulalie and Her Descendants v. Long \& Mabry 11 La. Ann. 463 (1856). See concurrence by Spofford, J. and Lea, J. 
person in question from slave to free. She would be relegated to a twilight legal status somewhere in between. ${ }^{46}$

\section{Conclusion and Epilogue}

On the other side of the Atlantic, the inchoate medieval doctrine that the "free air" of Britain conferred freedom had been mobilized in the late eighteenth century for the purposes of abolitionism, in conjunction with the famous Somerset $v$ Stewart decision that narrowed the scope of slaveholders' rights if they attempted to bring slaves into Britain itself. ${ }^{47}$ The opposite, however, occurred in nineteenth century Louisiana: A medieval doctrine of freedom through the passage of time lived "as free," part of a larger set of rules concerning liberty and status, was reduced by Louisiana's codifiers to a shard of property law, and then undermined as a tool for achieving a change in status.

Vernacular legal understandings nonetheless kept the idea of "freedom by prescription" alive in popular and even judicial memory. An underlying norm seems to have persisted, by which persons whose social position and behavior had shown them to be free of dominion in fact would eventually be entitled to a legal status to match. It was that norm that the slave traders' attorney R. H. Marr was trying to extinguish, arguing that persons once slaves could not via good-faith possession of themselves acquire the civil status of freedom.

Within a few years after the 1856 decision in Eulalie et al. vs. Long \& Mabry, all of this reasoning was in most respects rendered moot. Louisiana's legislature voted to secede and join the Confederacy, only to see New Orleans and then the bayou parishes occupied by Union forces beginning in April of 1862. Soon after the war ended, Louisiana's government was dramatically transformed. A newly expanded electorate, including men who had a few years before been enslaved, sent representatives to a cross-racial constitutional convention, and ratified the resulting radical state constitution. ${ }^{48}$

Born under Spanish rule, married during the territorial period, kidnapped for sale into slavery in the antebellum years, set at liberty shortly before the

46. For the official printing of the decision, and the headnote in question, see Reports of Cases Argued and Determined in The Supreme Court of Louisiana, vol. XI, For the Year 1856, W. M. Randolph, Reporter (New Orleans: Printed at the Offices of the Louisiana Courier, 1857), 463-64.

47. For a recent discussion of Somerset, see Patricia Hagler Minter, “"The State of Slavery': Somerset, The Slave, Grace, and the Rise of Pro-Slavery and Anti-Slavery Constitutionalism in the Nineteenth-Century Atlantic World," Slavery \& Abolition 36 (2015): 603-17.

48. On the 1868 Constitution, see Rebecca J. Scott, "Public Rights, Social Equality, and the Conceptual Roots of the Plessy Challenge," Michigan Law Review 106 (2008): 777-804. 
Dred Scott decision, and speaking Pointe Coupée Creole through it all, Eulalie Oliveau survived to see these transformations. With the ratification of the 1868 Louisiana Constitution, she was recognized as a citizen of the state of Louisiana. With the ratification of the Fourteenth Amendment to the United States Constitution, the federal government formally confirmed that she was a citizen of the United States. In 1870, the census-taker found her at age 80, still living in Pointe Coupée, with her daughter and a small granddaughter, also named Eulalie. ${ }^{49}$

The underlying conflict over the relationship between ownership and civil status, however, had not subsided. The narrow interpretation of status advocated back in 1856 by the kidnappers' lawyer R. H. Marr took a new form after the Civil War. The Thirteenth Amendment, Marr might now have to concede, did indeed abolish the ownership of property in persons. But he and his allies hoped to assure that the change in status of persons once held as slaves would be very limited. Those whose freedom was ratified by the Thirteenth Amendment might no longer be claimable as property. But in Marr's view they did not thereby acquire the affirmative rights that otherwise accompanied "civil status" as free persons.

R. H. Marr, who had honed his skills in the antebellum courts of slavery's great metropolis of New Orleans, soon became a leader in the campaign to consolidate white supremacy and overturn state and federal civil rights laws. After arguing that pardoned former Confederates should be readmitted to the bar without having to take the "test oath," Marr became part of the legal brain trust centered on John Archibald Campbell. ${ }^{50} \mathrm{He}$ stepped forward to represent the men accused of the 1873 Colfax massacre of black voters, and helped to win the resulting case, U.S. v Cruikshank, dramatically undercutting the Enforcement Act of 1870 that had tried to extend federal protection of voting rights. Along the way, Marr also led the committee that incited the white supremacist insurrection of September 14, 1874, against the Republican government of Louisiana. ${ }^{51}$

49. See Family 60, Twelfth Ward, Parish of Pointe Coupée, Louisiana, Ninth Census of the United States, USNA, reproduced on USNA Microcopy 593, accessed through ancestry.com.

50. Marr filed his own appeal for admission to the bar in conjunction with the United States Supreme Court case Ex parte Garland 71 U.S. 333. On the New Orleans bar, see Michael Ross, "Obstructing Reconstruction: John Archibald Campbell and the Legal Campaign against Louisiana's Republican Government," Civil War History 49 (2003): 235-53.

51. Charles Lane, The Day Freedom Died: The Colfax Massacre, the Supreme Court, and the Betrayal of Reconstruction (New York: Henry Holt, 2008). For an admiring account of the insurrection, and Marr's role in it, see Louisiana State Museum, Carpet-Bag Misrule in Louisiana: The Tragedy of the Reconstruction Era Following the War between the States (New Orleans: Louisiana State Museum, 1938). 
In 1877, the United States Supreme Court heard from Marr again, as he argued the case for a steamboat owner who had refused a stateroom to Josephine Decuir on the grounds that she was a woman of color. This time, Marr argued against the constitutionality of state legislation that might affect interstate commerce, specifically Louisiana's equal "public rights" statutes. Marr won a decision, Hall v. Decuir, that helped render the state's Reconstruction Era antidiscrimination legislation nearly unenforceable. ${ }^{52}$

As he had sought to assure that there would be no true "freedom by prescription," Marr now sought to constrain the liberty seemingly assured by the Thirteenth and Fourteenth Amendments. In arguing the case against Eulalie Oliveau in 1856, he had persuaded two members of the Louisiana Supreme Court that whereas a person might be judged to be free of specific claims of ownership, "The public have an overruling interest in the question of his status." The concurring justices had, therefore, insisted that the state was not required to recognize the civil freedom of "all such slaves as their masters may choose to turn loose for the space of ten years." 53

By the 1870s, Marr was aiming to ensure an analogous lack of civil status for those whom the Thirteenth Amendment had released from the formal bonds of ownership. As lawyers and as citizens, Marr and his associates would seek to extinguish both the everyday exercise of freedom by the formerly enslaved, and the legal rights that might accompany it.

Here, perhaps, is a point at which historical inquiry may again intersect with contemporary legal analysis. In the nineteenth century, the seemingly legal exercise of the powers attaching to a right of ownership over a person could be grounded in rootless titles and momentary performances of possession. When such claims were challenged, the determination of status was open to rancorous dispute. Discerning whether conditions analogous to slavery have been imposed upon legally free workers today can be equally disputed and rancorous, and often turns now as it did then on both definitional debates and the interpretation of social relations. Linking the past to the present in this way does not presume equivalence, nor should it diminish the specificity of the experiences of Adélaïde Métayer or Eulalie Oliveau. But it may serve as a reminder that reducing someone to a condition of un-freedom in the absence of legal title is nothing new. It was part of how slavery worked all along.

52. On Hall v. DeCuir and the challenge to the state's antidiscrimination statutes see Scott, "Public Rights."

53. Eulalie and Her Descendants v. Long \& Mabry 11 La. Ann. 463 (1856). Concurrence by Spofford, J. and Lea, J. 